\title{
VERBAL AND NONVERBAL MEANS OF INFLUENCING THE ADDRESSEE IN THE MODERN ENGLISH DISCOURSE OF COMICS
}

Yemeyanova O. V., PhD of Philological Sciences, Associate Professor

ORCID ID: https://orcid.org/0000-0002-3277-1227

Odnoral O. A., student

Sumy State University,

2, Rymskoho-Korsakova St., Sumy, 40007, Ukraine

E-mail: yelenayemelyanova@ukr.net

In this research the modern English discourse of comics is investigated. The aim of this research is to uncover the means of influencing the addressee used in the modern English discourse of comics. To reach this aim, the notions of the discourse of comics and the verbal and nonverbal communication and means of influencing were determined. The following research is devoted to the features of the modern English discourse of comics and the kinds of verbal and nonverbal means of influencing the addressee used in the modern English discourse of comics.

The researched material proves that the addressee of the modern English discourse of comics is efficiently influenced by such verbal means as onomatopoeia (sound imitation), interjections, omission of language rules, an appeal to the reader, pun, the usage of slang, jargon etc. Among the nonverbal means we have found text formatting, text location, the stylization of balloons, pictograms and ideograms, visual metaphors and others.

Key words: discourse, the modern English discourse of comics, verbal means of communication, nonverbal means of communication, addressee.

https://doi.org/10.21272/Ftrk.2018.10(4)-2

Introduction. The modern English discourse of comics draws linguists' attention as a vibrant mix of verbal and nonverbal means of communication. The popularity of comics has receded a bit comparing with the $20^{\text {th }}$ century. A major part of their audience has been captured by films with all that bright visual and sound effects. That is why many comics have been transferred from paper to screens, especially comics about superheroes. But still, comics are still quite popular because of their special kind of narration that attracts a wide range of audience.

The discourse of comic books was studied by S. McCloud [18], E. Wong [28], F. Zanettin [29], L. G. Stolyarova [6] and others.

A comic is a medium that consists of juxtaposed sequences of panels of images with speech balloons that contain text [11]. The modern English discourse of comics abounds in both linguistic and extralinguistic elements. Communication means of verbal and nonverbal levels are aimed at affecting the addressee, making him/her drown into a certain communicational situation shown in a comic, they make it interactive.

To achieve this goal authors of comics usually resort to:

1. Verbal means of influencing the addressee represented by pictures and nonverbal signs.

2. Text itself that represents verbal means of influencing the comics' addressee.

The aim of this research is to uncover the means of influencing the addressee used in the modern English discourse of comics.

The tasks of the research are to:

1. Uncover the notions of discourse, comic, verbal and nonverbal communication.

2. Study the features of the modern English discourse of comics.

3. Determine the kinds of verbal and nonverbal means of influencing the addressee that are used in the modern English discourse of comics.

(C) Yemeyanova O. V., Odnoral O. A., 2018 
In this article we used descriptive and comparative methods of research. With the help of descriptive method, we determined elements and features of the modern English discourse of comics, and the verbal and nonverbal means of influencing the addressee.

The relevance of the research is stipulated by the dominance of the anthropological approach to the study of the modern English discourse of comics as a linguistic phenomenon. By studying the features of this type of discourse and its means of the addressee's influence, firstly, we can develop the field of creating comics as a branch of literature. And, secondly, find out in which ways comics and means used in them can impact the reader. It can serve as a ground for further studies about where comics and such means be used to increase expressiveness of media or any other discourse.

The subject area of the research is the modern English discourse of comics as the type of the literary discourse.

The specific topic of the research are verbal and nonverbal means of influencing the addressee in the modern English discourse of comics.

Results of the research. Referring to the modern literary guide, we can define discourse as "a fragment of oral or written language, which reflects social, epistemological, artistic practice and can influence it" [3, p.67], so, it is a language in the process and environment of its use.

Discourse reflects a real worldview and reacts to its changes. Through research of some discourse one can observe changes in language and speech which are caused by diverge extralinguistic factors, i.e. external conditions that influence the text, and deduce the tendencies in these changes.

The modern English discourse of comics as the type of the literary discourse has some distinctive characteristics. As a kind of literary discourse, it includes the inner world of a comic book, the intensions of the author and how a reader perceives and interacts with all the information and means of influencing the addressee.

There are many definitions of a comic book, but they all, in general, come down to the fact that a comic book is a series of images that tells a story. According to most researchers, a comic book is a unity of narrative and visual action. Scott McCloud, the author of the book "Understanding Comics", offers a brief definition of "sequential images", and more complete - "related drawings and other images in a semantic sequence" [18]. It is literary a story told by pictures.

There is a big variety of kinds and genres of comics. In general, they can be divided into such types:

1. Superhero comic books are like modern mythology, because of its fantastical settings and characters with supernatural powers. There are such superhero comics as Superman, Spiderman, Batman and many others.

2. Alternative/esoteric comic books are more realistic than superhero comics, although they do not necessarily have to be real to life. They are usually chosen by readers who want to think a bit more about what they are reading. Some alternative comics can describe fictional events, while others are educational or based on history. These comic books tend to receive more critical recognition and acclaim.

3. Manga comic books are Japanese, but they have become so popular, that are also produced in other countries. Manga is the most well-known comic book type worldwide.

4. Science Fiction/Fantasy comic books. Science fiction comic books tell futuristic stories. They incorporate advanced technologies and space travelling. Many superhero comics also fall under this category because of the weapons and devices they include. Nonetheless, superhero comic books belong to their own category. Fantasy comic books are like fairytales. They involve fantasy creatures, sorcery, and mythological figures.

5. Action/adventure comic books usually involve characters that do not have special powers. They tell about everyday people with their life problems or hard challenges. Most of the characters are detectives or policemen, and the story focuses on their battles against criminals. 
6. Horror comic books feature characters such as zombies, monsters, and vampires. They intend to frighten their readers. They can either be supernatural or non-supernatural. Such comics aim to provoke a response: psychological, emotional, or a physical reaction to fear.

7. Children's comics are generally whimsical and humorous and geared towards children.

8. Romance comic books are stories about love and relationships. They can also cross over to other genres. Comics that are strictly about romance are no longer popular.

9. Adult comic books are the underground publications of the genre and cannot be found in mainstream bookstores and even comic book shops. Nonetheless, they are very popular on the Internet $[15 ; 26]$.

Comics do not necessarily have text, there are textless comics with an intuitive plot. But most of the direct speech in a comic is transmitted using the "word bubble" or "balloon", which is usually depicted as a cloud coming out of the mouth, or, in the case of the image of thoughts, from the head of the character. The words of the author are usually placed above or below the comic strips [11].

Comics can differ by their literary genre, and the style of drawing. Even some works of classic literature are adapted to them. But historically, the most common genres of comic books are adventurous stories and caricatures. This stereotype has long spoiled the reputation of comics.

By size comics vary from short "stripes" of several (usually three) pictures to largescale graphic novels and series of many releases. The drawing in a comic has a certain degree of conventionality. It is simplified for faster drawing and convenience of perceiving and identifying the reader with the character [18].

A comic is closely tied to the cinema, and especially to animation. As McCloud notes, "A film is a very slow comic strip. For a comic book space means the same thing as time for a film" [18]. In English, the word "cartoon" - "caricature" can mean both a comic book and a cartoon [10].

Since the moment comics appeared, periodicals were used as the main form of their distribution, which initially focused on the wide audience. It should also be noted that the discourse of comics developed in anthropocentric traditions as a special type of human exposure. Literature, as well as other forms of art, is a special communicative sphere that foresees the interaction of two key elements of the communicative act - the author and the addressee (in our case it is the reader or listener). A literary text becomes a discourse as soon as the reader is immersed in reading and begins to interact with the author. The literary discourse is understood as a coherent process of interaction between the text and the real reader, who considers or violates the "instructions" of the author, that introduces the text information to the reader in the context of the communicative situation and extralinguistic factors. Texts of fiction are texts with a clearly ambiguous interpretation. Such a category of discourse as implicacy, the presence of an indirect meaning, manifests itself in the comic as a context [6, p. 278].

The key feature of the modern English discourse of comics is the unity of text and graphic elements that perform the function of composite and topic-rhetorical division, the function of distinguishing communicatively significant elements. Therefore, it contains the verbal and nonverbal constituents.

Verbal communication is a way of transmitting information that involves a purposeful verbal way of exchanging certain messages linguistic side of which has a hierarchical structure (from phonemes to text and intertext) and acts in different stylistic varieties (spoken and literary language, dialects and sociolects, different styles and genres) $[11 ; 6$, p. 280].

The verbal constituent primarily conveys a dialogue of the characters. The figure and the verbal text contained therein form an organic semantic unity. Verbal components comprise the letter text and the whole speech unity within the comic strip. There are two subtypes of the speech: author's one and the speech of the characters [11]. 
In literature nonverbal messages, which are created with the help of any other sign system, are usually verbalized - decoded with the use of language means. For example, a red-light signal can be translated as "passage closed", "stop"; a raised finger, covered by the palm of another hand as "I'm asking for an extra minute of a break" in sports competitions, etc. But in comics non-verbal means play a much bigger role. The extralinguistic system of signs is a very important addition to the verbal constituent and perform the function of facsification [6, p. 280].

Considering the recent trends in the study of non-verbal means of communication, it seems appropriate to classify nonverbal means of communication into the following components:

1. Paralinguistics, the object of which is vocalization, that is, the quality of voice, intonation, pause, etc.

2. Opti-kinetic system, which includes gestures, facial expressions, pantomimetics.

3. Proxemic, focused on the characterization of spatial needs of a person [4].

In a comic book non-verbal components include a comic strip and paragraphics. The basis of paralinguistic means used in the comic can be both linguistic and non-linguistic. For example, on a linguistic basis there is a stylistic use of capital letters and punctuation marks, and on non-linguistic -placement of the text, use of colors and fonts [11].

By the interaction of verbal and non-verbal components in it, a comic book combines a high amount of information designed for maximum ease of perception. The main objective of combining linguistic and extra-linguistic factors is the impact on the recipient. Like other texts related to visual agitation, it is intended for the rapid and effective transmission of the message. Originally, comic books are targeted to the wide audience.

So, one can distinguish the following functions performed by the above listed means of expression in comics:

1. The function of language means economy.

2. Expressive function.

3. Sound-imaging function.

4. Simplifying function.

5. Descriptive function.

6. Characterizing function.

7. Identification function.

8. Function of intensification of emotional influence.

9. Aesthetic function [5].

After studying the linguistic content and features of the replicas in several English comics, we have concluded that a big amount of space is occupied by such verbal and nonverbal means as sound imitations and interjections, pictograms and ideograms, special spelling and punctuation, and the features of formatting the text.

Verbal components include "means of the language code, that are, words, phrases, sentences (messages), texts by which information is transmitted. Verbal components are the most important components of a communicative act, because in normal (non-specialized) impersonal communication they serve as the main carriers of the messages' meanings" $[1$, c. 57-58].

A verbal code is a collection of linguistic means used for communicative purposes and characterized by certain homogeneity [29, c. 24].

The verbal component, firstly, transmits the dialogue of its characters. Together pictures and text form an organic semantic unity. The verbal components in a comic include replicas and all text unities. There are two subtypes of speech: speech of the author and speech of the characters [6, c. 280].

There two ways of interpreting a text, which depend on the intention of the author, or the result of his work, that is, the final perception of the text by the recipient. Proceeding from this statement, it is expedient to consider comics from the point of view of their stylistic. In comics one can find such stylistic means as the use of stylistically colored vocabulary and means of syntax with implicative expression [2, c. 20]. 
An appeal to the reader is a very effective means of influencing the addressee [2, c. 21]. Literary works, which are filled with such means, are called "metaprose", that explores the connection between literature and reality, life and art [19]. Such comics make the reader to simultaneously realize that he/she is currently in the process of reading, and feel the authenticity of the text, when the reality of comics "penetrates" into our world. In the modern English discourse of comics, it can be found quite often. The author may refer to the reader, for example:

"How to take on a cave full of orcs and not take any damage?" [13].

But most often the audience of the modern English discourse of comics is addressed by the characters themselves, for example:

"Imagine how your 3-D world appears to me" [20].

The most "talkative" comic among all that we have investigated is "Deadpool", created by F. Nisieza and R. Liefeld in the publication "Marvel Comics". In addition to the usual appeal to the addressee, the author tries to predict his readers' thoughts, creating an effect of unexpectedness. When the addressee sees his thoughts pre-written on the paper, he feels pleasure from such a coincidence. Usually such "thoughts" are funny and emphasize humorousness of the comic, even in serious or sad moments (battle, death of the protagonist etc.). For ex.:

"So just tell him, already! What's the big deal?" [28].

The following means of influencing the addressee make the replica in comics more expressive.

Onomatopoeia (sound imitation) is a textual reproduction of the sounds of nature and the sounds that accompany some processes (shaking, laughter, whistling, etc.). It is the most used among other means in the comics that we have researched. Sound phenomena are usually not considered as lexical. But speaking of the use and role of these words in comics, one can agree that although they have no nominative function, these words have lexical meaning and function as full words, because native speakers use them as a means of communication [5]. For example, "slput", "beedle", "thock!", "ssshick" "fooomf", "bark", "shoop!" [14], etc.

There different kinds of onomatopoeia:

1. The words, that imitate the voices of birds.

2. The words, that imitate the voices of animals.

3. The words, that imitate the human sounds.

4. The words that represent the sounds of nature, such as wind, rain, storm.

5. The words that imitate different sounds that do not belong to living creatures [5].

The so-called verbal interjections are similar to sound imitations. One of their features is repetition [5].

Comics are also full of interjections, which are words that directly express feelings, experiences and expressions of will, without naming them, for example: "Sheesh!", “Waaaaa!", "Pssst” [9].

A distinctive feature of the modern discourse of the American comics is the representation of sleep or snoring using the letter " $Z$ ", which is also an onomatopoeia. Previously, there were a lot of letters in a row, for example: "ZZZZZ ...", but today this practice is reduced to the one letter " $Z$ " that saves space [24].

In comics one can also notice that spelling and punctuation rules may be omitted. This is done to make the speech sound in a special way, expressing the mood and feelings of the characters. In the comics that we have explored, the author thus shows that the character is either ignorant, grew up on the street, or just too "cool" to use the correct language, for example:

"Wuh for dinner, woomun?"

"Me take photo for Eenstagram."

"I dunno."

"Because dey is da ones you eat."

"Didja hear that, guys? The rat here thinks he don't hafta give Jeffy his smokes" [25]. 
Based on the information above, we can say that the verbal components of a comic strip include a strop (a sequence of drawings) and a paragraph.

In the comic strip, we can see facial expressions, gestures, intonation of characters, their manifestations of emotions and feelings, that is, their non-verbal behavior. Non-verbal communication of both comic book characters and the author with the reader occurs through paralinguistic means, which can be both linguistic and non-verbal. As an example, the linguistic basis can be stylistic use of capital letters and punctuation marks, and in nonlanguage - the placement of text, the use of color and fonts [10].

As for non-verbal means in the contemporary English discourse of comics, the most used means is text formatting. One of its functions is to emphasize the mood and feelings of a character (joy, interest, surprise, anger, doubt, excitement, fear, etc.). But is can also be used to emphasize a certain word or a phrase by changing the shape of the letters (font size, type, form, location), for example:

"What?"

"The marines?"

"Fun? So's welfare! Does that make it right?" [25].

In comics one can rarely find simple fonts such as Arial or Times New Roman. Fonts specifically designed for comics, such as Comic Sans, are used most often but, according to current trends, are outdated. Modern comics artists use a big variety of new interesting fonts $[8 ; 7]$. In the modern English discourse of comics one can often find fonts similar to handwriting.

The text of the modern English comics is usually entirely written in capital letters, which creates additional expressiveness and facilitates its perception. The exceptions are a certain type of surname that begins with "Mc ..." and such interjections as "er", "um", etc. Small letters also denote whisper, silent, frightened or uncertain voice [24; 23].

Choosing the right font for a comic is very important. An unsuccessful form of letters can spoil the impression of a picture, and letters which are difficult to distinguish - to make the reader postpone the book forever [7].

In comics, an important role is played not only by the form of its letters and words, but also by the form of their placement - in a balloon (speech bubble). Even though the most commonly used classical form of a balloon is oval, there is a huge amount of their stylizations. They can express the mood of the character: curves can transmit softness, dreaminess; straight lines, balloons in the form of an explosion, lightning or shatters express the same "prickly" emotions: anger, fear, surprise [28]. Balloons drawn with a dotted line denote whisper. The balloons that express scream tend to have a toothed contour or thicker lines that can be colored. The text in such speech bubbles is usually larger or written in bold type [24]. They can also be styled according to a specific subject, for example, if it's a horror comic, balloons may have spider webs on them. Rectangular speech bubbles that do not "stretch" their tail to any of the characters serves as a remark of the author [24].

Balloons may have different colors that affect the perception of the text. For example, a red background can express the speaker's anger, pink - a romantic mood, green - envy. A replica can be divided into several cylinders. This indicates a pause in the speech of the character, expressing his anxiety, insecurity, fear or mysteriousness [8].

The tails of the balloons indicate the source of a replica. There are two types of them: a straight or curved tail that narrows towards the source; a chain of bubbles, which decreases in the direction of the speaker. The "line" tail denotes speech, the "bubble" tail denotes thought. A few tails in one balloon represents the speech of several characters at the same time. Sometimes a balloon contains a smaller one inside - this is an additional thought that flashed in the head of the character [8].

One of the most distinctive features of comic discourse is the use of a single punctuation mark to represent the character's emotions, which is a much more effective means of influencing the addressee than any possible utterance. A speech bubble with one big question mark "?" (Often drawn by hand, not considered as a part of the text) means 
confusion or not knowing. The exclamation mark "!" is a surprise or a horror. Sometimes punctuation marks are placed separately above the head of a character without the need for a balloon [24].

A pictogram is one of the simplest (and most popular) forms of data visualization, the symbol that denotes a thing because of its similarity to a physical object. They are very often used in comics, making simple information more visually interesting, attractive and easy to remember, impressing the recipient. This is a schematic representation of objects and phenomena that are converted into ordinary signs. They can be both inside a balloon and outside. A well-known example of a lit light bulb, which means an idea, is known to everyone. When reading pictograms, the addressee decodes the signs into their own language. They can be understood by speakers of any language [27; 17]. In the modern English discourse of comics, we have found such pictograms:

1. A lit light bulb (an idea).

2. Stars or planets above the head (feeling dizzy).

3. A cup of tea (pause).

4. Music notes (singing, music, whistling).

5. A lightning bolt (electricity, tension).

6. Two hands together (prayer).

Ideograms are graphic symbols that represent abstract phenomena or ideas. They do not indicate natural phenomena that can be touched. They regard to a consensual thought and are expressed by geometric lines and forms. Such signs are also intercultural. According to our research, the modern English discourse of comics most often contains the "no" ideogram, which looks like a circle with a line that through it, and an arrow indicating the direction of motion $[16 ; 22]$.

Pictograms and ideograms increase the expressiveness of a text or replace expressive means. They make the perception of comics easier and deeply impact the reader.

Another interesting means of influencing the addressee in the modern English discourse of comics is visual metaphor. It is a representation of things, actions or ideas through a visual image that offers a certain association or point of similarity. This tool is also known as a pictorial metaphor or simile [21; 12]. It often carries humorous or ironic connotation.

Conclusions. A comic is a mix of text and pictures that complement each other to make a bright story. It consists of a sequence of images that also contain nonverbal signs, such as pictograms, ideograms and replicas in special fields called "speech balloons".

The modern English discourse of comics is anthropocentric and is targeted at wide audience. Its aim is to impress its addressees, get them involved, make the comics easer to perceive, that is done with the help of various verbal and nonverbal means.

Among verbal means of influencing the address we differentiate the following: onomatopoeia (sound imitation), interjections, omission of language rules, an appeal to the reader, idioms, pun, the usage of slang and jargon. Nonverbal means include text formatting, text location, the form of speech bubbles, pictograms and ideograms, punctuation marks as a replacement of a phrase, visual metaphors and others.

Such means of influencing the addressee, combined with each other, due to their brightness, allow the modern English discourse of comics to effectively appeal to the emotional state of the addressee. This makes the content of the text easy to perceive, and makes a comic book more interesting, that makes the reader interact with the author and the characters of comics, becoming not just a spectator, but a part of their discourse. This, in turn, guarantees the popularity of comics among a wide range of readers. 


\section{ВЕРБАЛЬНІ ТА НЕВЕРБАЛЬНІ ЗАСОБИ ВПЛИВУ НА АДРЕСАТА У СУЧАСНОМУ АНГЛОМОВНОМУ ДИСКУРСІ КОМІКСІВ (ПЕРЕКЛАДАЦЬКИЙ АСПЕКТ)}

Смельянова О. В., канд. філол. наук, дочент

ORCID ID: https://orcid.org/0000-0002-3277-1227

Однорал О. А., студентка

Сумський державний університет,

вул. Римського-Корсакова, 2, Суми, 40007, Украӥна

E-mail: yelenayemelyanova@ukr.net

У науковій роботі досліджується сучасний англомовний дискурс коміксів. Мета роботи полягає у вивченні особливостей англомовного дискурсу коміксів, визначенні видів вербальних і невербальних засобів впливу на адресата, які використовуються в англійському дискурсі коміксів.

При дослідженні теоретичного матеріалу, розглядалися праџі таких лінгвістів як С. МакКлауд [18], Е. Вонг [28], Ф. Занеттін [29], Л. Г. Столярова [6] та інших. Практична частина роботи базується на матеріалі сучасних найпопулярніших англомовних коміксів, а саме “Doоnеsbury” (Г. Трюдо) [25], “Garfield” (Дж. Девіс) [14], “FoxTrot” (Б. Аменд) [9].

Досліджуваний матеріал свідчить, щуо для сучасного англомовного дискурсу коміксів характерним $\epsilon$ уживання наступних вербальних засобів впливу на адресата: ономатопея (імітація звуку), вигуки, порушення мовних правил, звернення до читача, використання ідіом, гри слів, сленгу, жаргону; та невербальних засобів, які включають форматування тексту, розташування тексту, стилізачія мовних кульок, піктограми й ідеограми, особливе використання пунктуаційних знаків, візуальні метафори.

Такі засоби впливу на адресата, поєднуючись між собою, завдяки свойй яскравості, дозволяють сучасному англомовному дискурсу коміксів ефективно апелювати до емоційного стану адресата. Це робить зміст тексту легким для сприйняття, а сам комікс цікавим, таким, щзо змушує читача взаємодіяти з автором та персонажами коміксів, стаючи не просто глядачем, а частиною їхнього дискурсу. Це, в свою чергу, гарантує коміксу популярність серед иирокого кола читачів.

Ключові слова: дискурс, сучасний англомовний дискурс коміксів, вербальні засоби комунікаиії, невербальні засоби комунікації, адресат.

\section{ВЕРБАЛЬНЫЕ И НЕВЕРБАЛЬНЫЕ СРЕДСТВА ВОЗДЕЙСТВИЯ НА АДРЕСАТА В СОВРЕМЕННОМ АНГЛОЯЗЫЧНОМ ДИСКУРСЕ КОМИКСОВ (ПЕРЕВОДЧЕСКИЙ АСПЕКТ)}

Емельянова Е.В., канд. филологических наук, доцент

ORCID ID: https://orcid.org/0000-0002-3277-1227

Однорал О.А., студентка

Сумской государственный университет,

ул. Римского-Корсакова, 2, Сумы, 40007, Украина

E-mail: yelenayemelyanova@ukr.net

В этой научной работе исследуется современный англоязычный дискурс комиксов. Цель исследования - выявить понятия дискурса, комикса, вербальной и невербальной коммуникации; изучить особенности англоязычного дискурса комиксов, определить виды вербальных и невербальных средств воздействия на адресата, которые используются в англоязычном дискурсе комиксов.

Проанализированный материал демонстрирует, что для современного англоязычного дискурса комиксов характерным является использование следующих вербальных средств воздействия на адресата: ономатопея (имитация звука), междометия, нарушение языковых правил, обращение к читателю, использование идиом, игры слов, сленга и жаргона; и невербальных средств, которые включают форматирование текста, расположение текста, стилизация баллонов, пиктограммы и идеограммь, визуальные метафоры.

Ключевые слова: дискурс, современный англоязычный дискурс комиксов, вербальные средства коммуникации, невербальные средства коммуникаџии, адресат.

\section{СПИСОК ВИКОРИСТАНИХ ДЖЕРЕЛ}

1. Бацевич Ф. С. Основи комунікативної лінгвістики : підручник / Ф. С. Бацевич. - [2-ге вид., доп.]. - К. : Вид. центр “Академія”, 2009. - 376 с. - (Серія “Альма-матер”).

2. Игнатова К. С. Языковые средства воздействия на адресата (читателя) у Э.А. По и возможности их интерпретации в русских переводах / Кристина Сергеевна Игнатова // Материалы Международного молодежного научного форума “ЛОМОНОСОВ-2012”. - 2012. - С. 18-26.

3. Літературний словник-довідник / за ред. Р.Т. Гром’яка, Ю.І. Коваліва, В.І. Теремка. - К. : ВЦ “Академія", 2007. - 752 с. - (Nota bene).

4. Мартинова О.М. Особливості вираження емоційних станів персонажів сучасної англійської літератури невербальними засобами [Електронний ресурс] / O. М. Мартинова // Studentam.Net.Ua. 2004. - Режим доступу до ресурсу: http://studentam.net.ua/content/view/8393/97/. - Дата доступу: 3.11.2018. 
5. Новый литературный жанр - комиксы и его языковые особенности [Електронный ресурс] / Н. Алемайкина, Д. Кирица, Я. Л. Алемайкина, Е. А. Петрова // Портфолио ученика. - 2007. - Режим доступа к ресурсу: https://портфолио-ученика.1сентября.pф/works/557778. - Дата доступа: 20.10.2018.

6. Столярова Л. Г. Комикс как тип дискурса / Л. Г. Столярова. - 2009. - С. 278-284.

7. Текст в комиксе, манге и $\mathrm{BD}$ [Электронный ресурс] // Мангалекторий. - 2013. - Режим доступа к pecypcy: http://mangalectory.ru/lessons/ml473. - Дата доступа: 5.11.18.

8. Функции текста и баллона в комиксе [Электронный ресурс] // WebComUnity - Режим доступа к pecypcy: http://webcomunity.net/blog/comicraft/1853.html. - Дата доступа: 2.11.18.

9. Amend B. FoxTrot [Electronic resource] / Bill Amend // GoComics - Access mode: https://www.gocomics.com/foxtrot/. - Accessed: 29.10.18.

10. Cartoon [Electronic resource] // Abby Lingvo Live - Access mode: https://www.lingvolive.com/ruru/translate/en-ru/cartoon. - Accessed: 25.10.2018.

11. Comics [Electronic resource] // Wikipedia - Access mode: https://en.wikipedia.org/wiki/ Comics - Accessed: 20.10.2018.

12. Commas Overview Presentation [Electronic resource] // Pinterest-Access mode: https://www.pinterest.de/pin/789185534678453318/. - Accessed: 3.11.18.

13. D\&D Comic Strip [Electronic resource] // LonnyUnitus. - 2015. - Accsess mode: http://www.lonnyunitus.com/blog/2015/3/20/dd-comic-strip. - Accessed: 10.11.18.

14. Davis J. Garfield [Electronic resource] / Jim Davis // GoComics - Access mode: www.gocomics.com/garfield/. - Accessed: 29.10.18.

15. How to Make a Comic/Types of Comics [Electronic resource] // WikiBooks - Access mode: https://en.wikibooks.org/wiki/How_to_Make_a_Comic/Types_of_Comics. -Accessed: 25.10.2018.

16. Ideogram vs Pictogram - What's the difference? [Electronic resource]// WikiDiff - Access mode: https://wikidiff.com/ideogram/pictogram. - Accessed: 2.11.18.

17. Kauranen R. Do You Speak Pictogram? [Electronic resource] / Ralf Kauranen // Multilingualism in Contemporary Literature in Finland. - 2016. - Access mode: http://www.monikielisyys.fi/en/blog/do-youspeak-pictogram/. - Accessed: 3.11.18.

18. McCloud S. Understanding Comics / Scott McCloud. - New York: HarperCollins Publishers, 1994.

19. Metafiction [Electronic resourse] // Wikipedia - Access mode: https://en.wikipedia.org/wiki/Metafiction. Accessed: 13.11.18.

20. Mitchell M. The Multiversity: Pax Americana 1 [Electronic resource] / M. Mitchell, R. Desaulniers // Retcon Punch. - 2014. - Access mode: https://retcon-punch.com/2014/12/01/the-multiversity-pax-americana-1/. Accessed: 10.11.18.

21. Nordquist R. Visual Metaphor [Electronic resource] / Richard Nordquist // ThoughtCo. - 2018. - Access mode: https://www.thoughtco.com/visual-metaphor-1692595. - Accessed: 1.11.18.

22. Papadopoulos A. Difference Between Pictograms and Ideograms [Electronic resource] / Arnold Papadopoulos // Pen and the Pad. - 2016. - Access mode: https://penandthepad.com/difference-between-pictogramsideograms-8434995.html. -Accessed: 3.11.2018.

23. Skirvin B. What font do comic books use? [Electronic resource] / Ben Skirvin // Quora. - 2017. - Access mode: https://www.quora.com/What-font-do-comic-books-use. - Accessed: 5.11.18.

24. Speech balloon [Electronic resource] // Wikipedia - Access mode: https://en.wikipedia.org/wiki/Speech balloon. - Accessed: 5.11.18.

25. Trudeau G. Doonesbury [Electronic resource] / Garry Trudeau // GoComics - Access mode: www.gocomics.com/doonesbury/. - Accessed: 1.11.18.

26. Types of comics [Electronic resource] // 2-Clicks Comics - Access mode: https://www.2-clickscomics.com/guide/types-of-comics.html. - Accessed: 25.10.2018.

27. What is a Pictogram and When Should I Use It? [Electronic resource] // Venngage - Access mode: https://venngage.com/blog/pictogram/. - Accessed: 3.11.18.

28. Wong E. Breaking the Silence: How Comics Visualize Sound [Electronic resourse] / Eric Wong // Sequart Organization. - 2014. - Access mode: http://sequart.org/magazine/53486/how-comics-visualize-sound/. Accessed: 13.11 .18 .

29. Zanettin F. Comics in Translation: An Overview [Electronic resource] / Federico Zanettin // Academia Access mode: https://www.academia.edu/10336050/Comics_in Translation_An_Overview. -Accesed: 17.11.18.

\section{REFERENCES}

1. Batsevich F. S. Basics of communicative linguistics.- [2nd ed., Additional.]. Kyiv : Publ. Center "Academy", 2009. 376 p. (The series “Alma Mater”).

2. Ignatova K. S. Linguistic means of influence on the addressee (reader) at E. A. Po and the possibilities of their interpretation in Russian translations. Materials of the International Youth Scientific Forum "LOMONOSOV2012”. 2012. P. 18-26.

3. Literary dictionary-directory / Ed. R. T. Gromyaka, Yu. I. Kovaliva, V. I. Teremka. Kyiv : Academic Center "Academia", 2007. 752 p.

4. Martynova O. M. Features of expression of emotional states of characters of modern English literature by non-verbal means. Studentam.Net.Ua. 2004. Access mode: http://studentam.net.ua/content/view/8393/97/. Accessed: 3.11.2018. 
5. Alemaykin N., Kiritsa D., Alemaykina Ya. L., Petrova E. A. New literary genre - comics and its linguistic features [Electronic resource]. Portfolio of the pupil. 2007. Access mode: https: //portfoliouchenica.sentrya.rf/works/557778. - Accessed: 10/20/2018.

6. Stolyarova L. G. Comics as a type of discourse. 2009. p. 278-284.

7. Text in comic book, manga and BD (2013). Mangalkotory. - Access mode: http://mangalectory.ru/lessons/ml473. - Accessed: 5.11.18

8. Text and Balloon Functions in the Comic Book [Electronic Resource]. WebComUnity - Resource Access mode: http://webcomunity.net/blog/comicraft/1853.html. - Accessed: 2.11.18.

9. Amend B. FoxTrot (2018).GoComics - Access mode: https://www.gocomics.com/foxtrot/. - Accessed: 29.10.18.

10. Cartoon (2018). Abby Lingvo Live - Access mode: https://www.lingvolive.com/ru-ru/translate/enru/cartoon. - Accessed: 25.10.2018.

11. Comics (2018). Wikipedia - Access mode: https://en.wikipedia.org/wiki/ Comics - Accessed: 20.10.2018.

12. Commas Overview Presentation. Pinterest - Access mode: https://www.pinterest.de/pin/789185534678453318/. - Accessed: 3.11.18.

13. D\&D Comic Strip (2015). LonnyUnitus. - Accsess mode: http://www.lonnyunitus.com/blog/2015/3/20/ddcomic-strip. - Accessed: 10.11.18.

14. Davis J. Garfield (2018). GoComics - Access mode: www.gocomics.com/garfield/. - Accessed: 29.10.18.

15. How to Make a Comic. Types of Comics (2018). WikiBooks - Access mode: https://en.wikibooks.org/wiki/How_to_Make_a_Comic/Types_of_Comics. -Accessed: 25.10.2018.

16. Ideogram vs Pictogram - What's the difference? (2018). WikiDiff - Access mode: https://wikidiff.com/ideogram/pictogram. - Accessed: 2.11.18.

17. Kauranen R. Do You Speak Pictogram? (2016). Multilingualism in Contemporary Literature in Finland. Access mode: http://www.monikielisyys.fi/en/blog/do-you-speak-pictogram/. - Accessed: 3.11.18.

18. McCloud S. Understanding Comics. New York: HarperCollins Publishers, 1994.

19. Metafiction. Wikipedia - Access mode: https://en.wikipedia.org/wiki/Metafiction. - Accessed: 13.11.18.

20. Mitchell M., Desaulniers R. (2014). The Multiversity: Pax Americana 1. Retcon Punch. - Access mode: https://retcon-punch.com/2014/12/01/the-multiversity-pax-americana-1/. - Accessed: 10.11.18.

21. Nordquist R. Visual Metaphor (2018). ThoughtCo. - Access mode: https://www.thoughtco.com/visualmetaphor-1692595. - Accessed: 1.11.18.

22. Papadopoulos A. (2016). Difference Between Pictograms and Ideograms. Pen and the Pad. - Access mode: https://penandthepad.com/difference-between-pictograms-ideograms-8434995.html. - Accessed: 3.11.2018.

23. Skirvin B. What font do comic books use? (2017). Quora. - Access mode: https://www.quora.com/What-fontdo-comic-books-use. - Accessed: 5.11.18.

24. Speech balloon. Wikipedia - Access mode: https://en.wikipedia.org/wiki/Speech balloon. - Accessed 5.11.18.

25. Trudeau G. Doonesbury. GoComics - Access mode: www.gocomics.com/doonesbury/. - Accessed: 1.11.18.

26. Types of comics. 2-Clicks Comics - Access mode: https://www.2-clicks-comics.com/guide/types-ofcomics.html. - Accessed: 25.10.2018.

27. What is a Pictogram and When Should I Use It? Venngage - Access mode: https://venngage.com/blog/pictogram/. - Accessed: 3.11.18.

28. Wong E. Breaking the Silence: How Comics Visualize Sound (2014). Sequart Organization. - 2014. - Access mode: http://sequart.org/magazine/53486/how-comics-visualize-sound/. - Accessed: 13.11.18.

29. Zanettin, Federico. Comics in Translation: An Overview. Academia. - Access mode: https://www.academia.edu/10336050/Comics_in_Translation_An_Overview. - Accesed: 17.11.18.

Received: 23 November, 2018 